\title{
Moderator Effects of the Employees' Gender on the Correlation between Facets of Job Satisfaction and Personality Dimensions
}

\author{
DOI: 10.7595/management.fon.2020.0003
}

\begin{abstract}
:
Research Question: The research is oriented towards determining the moderator effects of the employees' gender (structure) on the correlation between other research constructs, i.e., personality dimensions and job satisfaction. Motivation: Previous research on the influence of employees' personality dimensions and gender as potential predictors of job satisfaction was also conducted in Serbia. However, no studies could be found in the literature focusing on identifying the moderating effect of the employees' gender on correlation between job satisfaction and personality dimensions. The results would be of practical importance and applicable in human resource management practice in different organizations, particularly in transitional societies. Idea: The main subject of this research is oriented towards the employees' dimensions of personality, according to the Big Five personality dimensions, on the one hand, and job satisfaction, on the other. The research was conducted within the conditions of transition, i.e., in the organization that will be under the organizational changes (such as privatization) in the following period. As transition may produce uncertainty of the job positions for the employees (especially within the large public-owned monopolistic enterprises), it could be considered that organizational changes, such as privatization, could affect job dissatisfaction to a significant extent. Data and Tools: The survey research was conducted within the large public-owned monopolistic enterprises in Serbia on the sample of 116 employees. Findings: The research results pointed out that the employees' gender significantly shaped the correlation between all of the personality dimensions, on the one hand, and different facets of job satisfaction, on the other. Namely, in case of male employees, statistical significance was shown between Extraversion and Pay, Extraversion and Operating Conditions, Conscientiousness and Pay, Conscientiousness and Rewards, Neuroticism and Benefits. In case of female employees, the statistical significance was shown between Agreeableness and Benefits, Conscientiousness and Benefits and finally between Neuroticism and Supervision. Contribution: The obtained results may have practical implications in the form of providing the database for further improvement of the human resource management within the transitional economies, such as Serbian.
\end{abstract}

Keywords: job satisfaction, personality dimensions, Big Five theory, gender structure, transitional economy

JEL classification: D79, D91, J53, J8, M12, M54, Z32, Z39.

\section{Introduction}

Nowadays, the main source of competitive advantage in business is related to skills and knowledge of the employees. In addition, the employees' job satisfaction is often considered in the literature as a significant predictor of organizational business performance (Chi \& Gursoy, 2009; De Leaniz \& Rodríguez, 2015). Studies on the employees' job satisfaction or their work motivation are typically based on a variety of sociological and psychological constructs (Arthaud-Day, Rode, \& Turnley, 2012; Lopez, Babin, \& Chung, 2009). One of the widely used psychological theories within the job satisfaction studies is the Big Five theory, oriented towards the five dimensions of personality: extraversion, neuroticism, conscientiousness, agreeableness and openness to new experiences (Howard, Medina, \& Howard, 1996). Numerous researchers focused their efforts on researching correlation between job satisfaction and the aforementioned employees' personality dimensions (Judge \& Zapata, 2015; Berglund, Johansson Seva, \& Strandh, 2016; Hahn, Gottschling, König, \& Spinath, 2016). It is also important to note that previous studies examined the influence of different fac- 
tors that might influence job satisfaction, including job insecurity (Hsieh \& Huang, 2017), status goal attainment (Harari, Thompson, \& Viswesvaran, 2018), organizational climate (Otken \& Cenkci, 2015), leadership style (Yeh et al., 2016), but also socio-demographic characteristics, such as employees' gender (Al-Ajmi, 2006; Mora \& Ferrer-i-Carbonell, 2009). Previous research on the influence of employees' personality dimensions and gender as potential predictors of job satisfaction (Matanovic, 2009) was also conducted in Serbia. However, no studies could be found in the literature focusing on identifying the moderating effect of the employees' gender on correlation between job satisfaction and personality dimensions.

The research was conducted in the largest company in Serbia, the public energy company Elektroprivreda Srbije (EPS), within its branch "MB Kolubara". EPS is the power backbone of Serbia, supplying electricity for about 3.5 million customers and, according to the company profile for 2018 , its revenue contributing with about $9 \%$ to the Serbian total budget revenue (EPS 2018). The "Kolubara" mine basin employs about 12000 workers and produces about 30 million tons of coal each year, providing for the generation of about $50 \%$ of electricity in EPS. Even though EPS is a public company, we consider conditions of transition (Janicijevic, 2017) for this organization, as the Serbian government considers, as conveyed to International Monetary Fund through the letter of intent, its transformation from a public into a joint-stock company, which could be also perceived by employees as a step toward possible future privatization. As transition may produce uncertainty of job positions for the employees (especially within the large public-owned monopolistic enterprises), organizational changes, such as privatization, can be presumed to cause significant job dissatisfaction (Atari, Barbaro, Sela, Shackelford, \& Chegeni, 2017; Sun, Kaufman, \& Smillie, 2018).

The main subjects of this research are dimensions of the employees' personality and their job satisfaction. The main task of the research is to determine their correlation, considering their gender structure, with the aim of providing a database that would enable the improvement of human resource management within the country in transition, such as Serbia.

\section{Literature Review}

\subsection{Job Satisfaction}

The job satisfaction definition that is widely used in the literature indicates that this construct is related to a pleasant and positive emotional state, arising from the evaluation of the job or overall work experience (Locke, 1976). The research conducted by Cronin, Brady and Hult (2000) showed that job satisfaction is a key variable that might affect the employees' intentions and their attitudes, which is the main reason why their job satisfaction is often researched within the organizational behaviour (Burke, Graham, \& Smith, 2005). Some of the following are the most frequently mentioned facets of the job satisfaction: pay, promotion, supervision, benefits, rewards, operating conditions, correlation with co-workers, nature of work and communication (Spector, 1997), which will also be researched into for the purpose of this paper.

Numerous studies pointed out that employees who are satisfied with their job usually show a higher quality of business performance and they usually have a higher level of trust in the business environment of the organization (Pantouvakis \& Bouranta, 2013; Hur, Moon, \& Jung, 2015). One of the most prominent researchers in the field of job satisfaction, Paul Spector (1997), highlighted the three main reasons that might determine the importance of the employees' job satisfaction and factors that could contribute to its increase. The first reason reflects a rise of the awareness that employees must be respected as individuals, with specific personality traits, that could contribute to the general success of the company. The second reason is that the evaluation of the employees' job satisfaction also serves as an indicator for the degree of employees' work effectiveness. The third reason is that the organization takes the importance of the employees' job satisfaction into consideration because it has a positive effect on the fulfilment of organizational goals, and it is manifested through the positive attitude of the employees' towards the realization of these goals, in case of a high level of job satisfaction, while in case of the employees' job dissatisfaction, it could cause their negative attitude (Spector, 1997).

\subsection{Personality Dimensions}

During the last two decades, there has been an increased interest among the researchers in determining the correlations between the employees' personality, job satisfaction and general work motivation, mainly on the basis that values at both individual and organizational levels have always been perceived as a guide for specific action (Janicijevic, 2017). There are numerous definitions of the concept of personality in the literature. One of the most cited definitions is established by Eysenck (1967), who considered a personality as a more or less stable organization of the character, temperament, intellect and physical constitution that might determinate specific adaptation to the environment. 
One of the basic questions in the psychology of personality is related to the nature and the number of fundamental and irreducible dimensions of personality, whose combination may significantly reflect the individual's personality. There are different approaches to this problem. One approach is defined within the Big Five theory of personality. With less variability, most of the authors pointed to the following five dimensions of personality: extraversion, neuroticism, conscientiousness, agreeableness and openness to new experiences (Walker \& Vetter, 2016; Atari et al., 2017; Sun et al., 2018).

The first personality dimension is designated as extraversion and it is characterized by sub-dimensions such as cheerfulness (activity), cordiality, sociability and the dominance of empathy. In the organizational environment, an extravert wants to establish interaction with the other members of the organization and to develop a good correlationship with them. Also, their desire for new experiences leads to readiness for accepting the challenging tasks, which, if successfully implemented, could lead to the establishment of successful correlationships with the superiors (Antoncic, Bratkovic Kregar, Singh, \& DeNoble, 2015; Ýrengün \& Arýkboða, 2015; Liang, Chia, \& Liang, 2015).

On the other hand, people with high level of neuroticism are prone to focus on the negative aspects of the other people, which decreases their social skills. In the organizational context, the individuals with a pronounced dimension of personality labelled as neuroticism are prone to initiate different conflicts with their supervisor. In general, it could be said that this dimension is distinguished by several sub-dimensions, such as the lack of the emotional stability, feeling pressure, dissatisfaction and concern (Antoncic et al., 2015; Ýrengün \& Arýkboða, 2015; Liang et al., 2015).

Furthermore, the third dimension of personality is designated as conscientiousness, characterized by subdimensions such as respecting the rules, systematic planning and performing the tasks, inflexibility and conformism. In an organizational environment, individuals with a high degree of conscientiousness are responsible, self-disciplined, persistent and productive, so this personality dimension is one of the best predictors of gaining the business success (Ýrengün \& Arýkboða, 2015; Liang et al., 2015).

An individual with a pronounced personality dimension of agreeableness is motivated by the establishment of closeness with other people, which is also of particular importance for working in a team. The employee with this pronounced personality dimension is oriented towards cooperation. Such a person is also sensitive and altruistic, but also expects to be treated in the same way. Therefore, it could be said that the dimension of the personality labelled as agreeableness is characterized by sub-dimensions such as consideration and tenderness toward the others, the conflict avoidance and willingness to forgive (Antoncic et al., 2015; Liang et al., 2015).

And finally, a person with a high degree of openness to new experiences is creative, with the ability to think in an unconventional way and easily adapt to different changes. The sub-dimensions characteristic of the openness to new experiences are independence, intellectual efficiency and intellectual curiosity (Antoncic et al., 2015; Ýrengün \& Arýkboða, 2015; Liang et al., 2015).

\subsection{Personality dimensions and job satisfaction}

The compatibility of the employees' personality and job requirements can positively affect their job satisfaction (Judge \& Zapata, 2015; Bui, 2017). The balance between the employees' personality dimensions and the organizational job requirements can result in a better usage of employees' skills and talents. Therefore, one of the main tasks of the managers should be oriented towards meeting the needs of the employees' personality, in order to achieve their better commitment to performing various business tasks (Arthaud-Day et al., 2012). A misbalance of personality and job characteristics, with dissatisfaction caused by situational factors, could lead to the emergence of: the conflicts among the employees, absenteeism, job abandonment and job fluctuation, indifference, alcoholism, workplace injuries, frequent illnesses, frequent diseases due to an increased sensitivity and reduced resistance of the stress-affected organism (Judge \& Zapata, 2015; Bui, 2017). On the other hand, a balance between the employees' personality dimensions and the organizational job requirements can result in a better usage of the employees' knowledge and skills, which is beneficial for the employees, because it may allow them to meet the needs for achieving and gaining higher job satisfaction and work motivation. The balance of personality dimensions and job requirements is also important for the organization, especially in the case of providing the quality when performing the business tasks. Therefore, one of the important tasks of the managers is to meet the needs of the employees' personality, in order to achieve their better commitment to the specific demands of the workplace (ArthaudDay et al., 2012; Judge \& Zapata, 2015; Bui, 2017). 


\subsection{Predictors in shaping job satisfaction}

Factors that can influence an increase or decrease in job satisfaction may be related to the employees' personal characteristics, such as: socio-demographic characteristics, personality dimensions, lifestyle, locus of control, cultural dimensions or the employees' value system (Chai, Das, \& Rao, 2012; Maruping \& Magni, 2012; Li \& Chang, 2016), but also the factors related to the work itself, including: challenging business tasks, degree of autonomy, importance of work, or complexity of business tasks (Donegani, McKay, \& Moro, 2012; Kilili \& Bozdaðlar, 2013; Choi, Kim, Lee, \& Lee, 2014; Tansel \& Gazîoðlu, 2014). There are also different social factors, such as: rewarding system, full or part-time work engagement, interpersonal correlations and feedbacks, family situation, image of the organization, or general socio-economic conditions (Eskildsen, Kristensen, \& Gjesing Antvor, 2010; Loh, Restubog, \& Gallois, 2010; Karin Andreassi, Lawter, Brockerhoff, \& Rutigliano, 2014).

Some of the research results (Mora, Ferrer-i-Carbonell, 2009) indicate that males show a higher level of job satisfaction than females. However, according to the results of another study (Okpara, Sqillace, \& Erondu, 2005; Jung, Jae Moon, \& Hahm, 2007), females may achieve a higher degree of job satisfaction than males, while there are also authors who consider that there are no significant differences in job satisfaction based on the gender differences (Al-Ajmi, 2006; Koyuncu, Burke, \& Fiksenbaum, 2006; Frye \& Mount, 2007; Petrovic, Jovanovic, Markovic, Armenski, \& Markovic, 2014). Females' expectations regarding job satisfaction may be lower compared to the expectations of the males, and they are sometimes easier to be reached (Kaiser, 2007). However, Kelly (1989) argues that evaluation results of the females' job satisfaction should be approached with a certain degree of caution because they could often be inclined to embellish their evaluation of job satisfaction, saying that they are satisfied with their job, even if they are not.

In addition to the impact of the gender on shaping the employees' job satisfaction, the impact of this sociodemographic characteristic could also be noticed in the case of shaping the personality dimensions. Thus, Chiorri, Marsh, Ubbiali and Donati, (2016) pointed out that personality dimensions: neuroticism, agreeableness, conscientiousness and openness to new experiences are typically more pronounced among the females, which is also proven in the study of Siegling, Furnham and Petrides (2015). On the other hand, limura and Taku (2017) emphasized extraversion, as a personality dimension that is more pronounced among the males.

In accordance with the presented results of the previously conducted research, this research was oriented towards determination of the moderation effect of the socio-demographic variable 'gender' on the correlation between the employees' personality dimensions according to the model of the Big Five and individual facets of their job satisfaction.

\section{Methodology}

\subsection{Instrument}

The survey contained three groups of questions. The first group of questions was related to the socio-demographic characteristics of the respondents. For the purpose of this research, the respondents' gender structure was the most important socio-demographic characteristic, as this research was focused on determining the moderating effects of the employees' gender structure on the correlation between the other research constructs, i.e., personality dimensions and job satisfaction. The second group of the questions was reused from the standardized questionnaire for Big Five Locator-BFL (Howard et al., 1996), for obtaining the values for five dimensions of personality. These five, previously defined, dimensions of personality were tested based on the questionnaire with 25 items, with equal number of items dedicated to each dimension. For example, the respondents were asked to grade (on the scale from 1 to 7 ) their desire for social interactions as one of the items related to Extraversion, their level of insecurity as one of the items for Neuroticism, how creative they are in their job performance as one of the items related to Openness to new experiences, the level of their kindness to others as one of the items related to Agreeableness, and as an example of the items for conscientiousness the level of quality of their job performance. In case of the questionnaire for job satisfaction, the respondents expressed the degree of their agreement or disagreement on the scale from 1 (I completely disagree) to 6 (I completely agree) with the items from the standardized questionnaire on job satisfaction, formulated by Paul Spector (Spector, 1997). This standardized questionnaire contains 36 items, which could be grouped into nine facets of job satisfaction. These facets of job satisfaction are: pay (example item: "I feel I am being paid a fair amount for the work I do"), promotion (example item: "There is really too little chance for promotion on my job"), supervision (example item: "My supervisor is quite competent in doing his/her job"), benefits (example item: "I am not satisfied with the benefits I receive"), rewards (exam- 
ple item: "When I do a good job, I receive the recognition for it that I should receive"), operating conditions (example item: "Many of our rules and procedures make doing a good job difficult"), correlation to co-workers (example item: "I like the people I work with"), nature of work (example item: "I sometimes feel my job is meaningless") and communication (example item: "Communications seem good within this organization").

\subsection{Sample}

The research was conducted in the public-owned organization within the energy sector, in a small town that is almost entirely oriented towards this energy complex. Other economic sectors are not significantly developed, although there are numerous opportunities for this, especially in the field of tourism (industrial tourism, cultural tourism, rural tourism). The sample consisted of 116 respondents, including male (44.8\%) and female respondents $(55.2 \%)$, out of 11,880 employees. The number of distributed questionnaires was 220 , with 138 received responses (response rate $62.7 \%$ ) and 116 surveys were considered for the analysis, i.e., only those which were fully completed. A long-standing monopolistic position and highly bureaucratic organizational culture of the large public organizations in Serbia, operating in the energy sector, influences the creation of a specific organizational environment. Such a situation further provides unfavourable psychological framework for the upcoming changes, related to the privatization, because job alternatives for these employees could be greatly reduced and, therefore, it is important to understand the research results within this setting.

\subsection{Procedure}

The research was conducted during the year 2016. All of the respondents participated voluntarily in the survey research. They were informed that the research is anonymous, and they were asked to fill in the questionnaire truthfully. Questionnaires were distributed in person within the organization, by using the standard pen-and-paper procedure. Obtained data were analyzed by using the Statistical Program for Social Sciences (SPSS 17.0). Descriptive statistics was used for analysing the respondents' demographic characteristics, while the main statistical findings were gained on the basis of analysing the effects of the moderator (gender, in this case) on the level of correlation between the main constructs of the research: job satisfaction and personality dimensions.

\subsection{Data analysis}

For data processing, we used descriptive statistics and correlation analysis. Further, we used a hierarchical regression analysis to investigate the moderating effect of Gender on the regression between facets of job satisfaction (as a dependent variable) and dimensions of personality (as an independent variable).

\section{Results}

In Table 1, the results of the Descriptive Statistics (mean and standard deviations) for the facet of job satisfaction and the dimensions of personality are provided. The table also gives the values of Cronbach's alpha for each dimension, which demonstrates their good reliability.

Table 1: Descriptive statistics

\begin{tabular}{|c|c|c|c|c|c|c|c|}
\hline Name & Abbrev. & N & Min & Max & Mean & Std. Dev. & $\alpha$ \\
\hline Pay & JSpay & 116 & 1.00 & 5.25 & 2.71 & .92 & .766 \\
Promotion & JSprom & 116 & 1.25 & 4.75 & 2.96 & .82 & .757 \\
Supervision & JSsup & 116 & 1.50 & 6.00 & 4.29 & .93 & .789 \\
Fringe Benefits & JSben & 116 & 1.00 & 5.25 & 2.85 & .87 & .762 \\
Contingent Rewards & JSrew & 116 & 1.00 & 5.00 & 2.76 & .84 & .761 \\
Operating Conditions & JSoc & 116 & 1.00 & 5.50 & 3.56 & .73 & .750 \\
Coworkers & JScow & 116 & 2.25 & 6.00 & 4.27 & .72 & .732 \\
Nature of Work & JSnow & 116 & 1.25 & 6.00 & 3.97 & .92 & .778 \\
Communication & JScom & 116 & 1.00 & 6.00 & 3.27 & .99 & .791 \\
Extraversion & BFextr & 116 & 2.40 & 7.00 & 5.58 & 1.19 & .772 \\
Openness to new & BFopen & 116 & 2.00 & 7.00 & 5.47 & 1.03 & .702 \\
experiences & BFagr & 116 & 2.00 & 7.00 & 5.76 & 1.10 & .859 \\
Agreeableness & BFcons & 116 & 2.00 & 7.00 & 6.15 & .90 & .780 \\
Conscientiousness & BFneur & 116 & 1.00 & 7.00 & 4.23 & 1.28 & .806 \\
Neuroticism & Valid N (listwise) & 116 & & & & & \\
\hline
\end{tabular}


The correlation between the facets of job satisfaction and the dimensions of personality is given in Table 2 . These results refer to the total sample of $\mathrm{N}=116$ respondents. Pearson correlation was used. In Table 2 , the statistically significant correlations were identified as follows: ${ }^{*} p<0.05 ;{ }^{* *} p<0.01$.

Table 2: Pearson coefficients of the correlation between facet of job satisfaction and the dimensions of personality

\begin{tabular}{|c|ccccc|}
\cline { 2 - 6 } \multicolumn{1}{c|}{} & BFextr & BFopen & BFagr & BFcons & BFneur \\
\hline JSpay & $-.199^{\star}$ & $-.244^{* *}$ & -.044 & $-.207^{*}$ & .116 \\
JSprom & .054 & -.036 & -.063 & -.004 & -.018 \\
JSsup & $.231^{*}$ & .075 & .059 & .021 & -.008 \\
JSben & -.126 & $-.184^{*}$ & -.073 & $-.247^{* *}$ & $.218^{*}$ \\
JSrew & -.028 & -.033 & .021 & -.171 & .070 \\
JSoc & -.071 & -.042 & .012 & .076 & .006 \\
JScow & .164 & .018 & .066 & -.018 & .095 \\
JSnow & .170 & -.021 & .029 & .068 & -.149 \\
JScom & .033 & .043 & .049 & -.076 & $.196^{*}$ \\
\hline
\end{tabular}

Gender as a moderator of the observed relations. First, the sample of $\mathrm{N}=116$ respondents was divided on the basis of gender of respondents. Thus, in one subgroup there were 52 male respondents and the other subgroup included 64 females respondents. The results of the correlation analysis between the facets of job satisfaction and the dimensions of personality for Gender are summarized in Table 3.

Table 3: Correlation coefficients between facet of job satisfaction and dimensions of personality for gender

\begin{tabular}{|c|cc|cc|cc|cc|cc|}
\cline { 2 - 11 } \multicolumn{1}{c|}{} & \multicolumn{2}{c|}{ BFextr } & \multicolumn{2}{c|}{ BFopen } & \multicolumn{2}{c|}{ BFagr } & \multicolumn{2}{c|}{ BFcons } & \multicolumn{2}{c|}{ BFneur } \\
\cline { 2 - 11 } \multicolumn{1}{c|}{} & $\mathrm{M}$ & $\mathrm{F}$ & $\mathrm{M}$ & $\mathrm{F}$ & $\mathrm{M}$ & $\mathrm{F}$ & $\mathrm{M}$ & $\mathrm{F}$ & $\mathrm{M}$ & $\mathrm{F}$ \\
\hline JSpay & $-.358^{\star^{*}}$ & -.071 & -.233 & $-.253^{\star}$ & -.018 & -.061 & $-.355^{\star \star}$ & -.116 & .123 & .123 \\
JSprom & .026 & .079 & -.028 & -.040 & -.016 & -.096 & -.192 & .108 & -.074 & .041 \\
JSsup & .193 & $.255^{\star}$ & .149 & .013 & .024 & .066 & .117 & -.042 & .140 & $.255^{\star}$ \\
JSben & -.019 & -.218 & -.099 &.$- .333^{\star *}$ & .153 & $-.241^{\star}$ & -.204 & $-.287^{\star}$ & $.502^{\star *}$ & -.056 \\
JSrew & -.023 & -.010 & .057 & -.090 & .083 & $-.269^{\star}$ & $-.281^{\star}$ & -.118 & .220 & -.015 \\
JSoc & $-.347^{\star}$ & .184 & -.246 & .124 & -.147 & .166 & -.086 & .193 & .021 & -.004 \\
JScow & .231 & .093 & .103 & -.058 & .141 & -.032 & -.026 & -.013 & .083 & .078 \\
JSnow & .262 & .109 & .005 & -.035 & -.063 & .108 & -.062 & .142 & -.161 & -.133 \\
JScom & .047 & .023 & .086 & .004 & .140 & -.046 & -.051 & -.106 & $.315^{*}$ & .069 \\
\hline
\end{tabular}

Hierarchical regression analysis. Hierarchical regression analysis examined the significance of the regression coefficient for the independent variables (dimensions of personality), the dependent variable (facets of job satisfaction), and Gender as the moderating variable.

The hierarchical regression analysis consists of three steps. In the first step dimensions of personality are predictors, in the second step dimensions of personality and gender are predictors, and in the last step, an interactive variable (centered) dimensions of personality $x$ gender are added into the model. The moderating effect was tested by examining the change in the R-squared attributable to the interaction term. If the interaction term added at the final stage of the regression analysis produced a significant R-squared (i.e., significantly increased the amount of variance explained in the outcome variable), the Gender can be said to be a moderator of the relationship between dimensions of personality and facets of job satisfaction. The Durbin-Watson test values are within the accepted range between 1,616 and 2,166 and it indicates that there was no autocorrelation problem with the data. The results of the hierarchical regression analysis (R-square and $\mathrm{F}$ change) are presented in Table 4, with only those results where the moderating effect of Gender was found. We further discuss only these results. 
Table 4: Hierarchical regression analysis ( $R$ square and F-change)

\begin{tabular}{|c|c|c|c|c|}
\hline \multicolumn{2}{|c|}{ Gender } & $\mathbf{R}^{2}$ & F Change & Sig. \\
\hline \multirow{2}{*}{ BFextr } & JSpay & .035 & 3.380 & .049 \\
& JSoc & .080 & 9.132 & .003 \\
\hline BFagr & JSben & .047 & 4.948 & .028 \\
\hline \multirow{3}{*}{ BFcons } & JSpay & .110 & 5.135 & .007 \\
& JSben & .142 & 5.316 & .006 \\
& JSrew & .086 & 3.987 & .021 \\
\hline \multirow{2}{*}{ BFneur } & JSsup & .035 & 4.104 & .045 \\
& JSben & .125 & 10.032 & .002 \\
\hline
\end{tabular}

\section{Discussion}

\subsection{Moderation effects in case of male employees}

Extraversion and the facets of job satisfaction. The research results show that an increase in personality dimension extraversion is followed by a decrease in the pay facet of job satisfaction among the male employees, which is not the case with the female employees. Extraversion, as a personality dimension, is characterized by openness for meetings and socializing with the other people, as well as by individual desire for affection, gaining a high status within the hierarchal scale and being in the centre of other people's attention (Imarinen, Vainikainen, Verkasalo, \& Lönnqvist, 2015). Research conducted by Lucas, Diener, Alexander, Eunkook and Shao (2000) show that only those sub-dimensions of extraversion related to sensitivity to rewards are in high correlation with the positive affectivity. The authors conclude that even though the sociability represents an important aspect of extraversion, it may be just one of the side effects to the high-sensitivity for rewards, which is present in individuals with high degree of extraversion. High affinity for rewards also means that there are high expectations among extraverts when it comes to gaining rewards (Oehler \& Wedlich, 2018). This means that a low degree of satisfaction on rewards will be formed if those expectations are not fulfilled (this is characteristic for both male and female extraverts). As salary represents one of the most important rewards, it can be said that expectations of high payments are represented among the extraverts (Kruyen, Keulemans, Borst, \& Helderman, 2019). However, males in particular are sensitive to this issue because money and material goods are important parameters of power, which is highly sought among the extravert men, who have ambitions to attain prestigious positions within the modern society. Thus, such ambition is characteristic for the male employees with a high level of extraversion and who, therefore, have a pronounced need for gaining higher personal income, in comparison to extravert females, who desire to achieve a high standard of living and successful correlation with the other members of society, which is furthermore accentuated in conditions of the transition and high level of hierarchy.

The second result indicates that with the increase in extraversion, satisfaction with operational conditions in male employees decreases. According to the questionnaire we used, good operating conditions imply that there are not many rules and procedures for good job execution. A male employee who has a pronounced extraversion is lively, sociable, loves to have fun. Hence the possible explanation of the result is that a job requiring much administration with many rules and procedures causes dissatisfaction with the operating conditions for male employees with pronounced extraversion. Female employees, on the other hand, may be more willing to follow the rules and procedures consistently, even in the case of their pronounced extraversion.

Conscientiousness and facets of job satisfaction. Based on the research results, it is evident that the increase in conscientiousness among the male employees is followed by a decrease in the pay facet of job satisfaction, which is not the case in the sub-sample of the female employees. In the sub-sample of the male employees, there is evidently a large number of employees with a high degree of education and those at managerial positions. These employees are usually faced with a necessity of solving complex tasks, so the quality of their performances can depend on the level of their conscientiousness. According to the questionnaire, used for the purpose of this survey research, high perception of conscientiousness implies that employees consider themselves as highly motivated for work (which is partly measured by the item on persistence in performing their business tasks). Therefore, they expect that their persistence, as well as high quality of their work performances, would be recognized by the management (or the owners). The high level of conscientiousness among the male employees, given the structure of this sub-sample, has significant organizational outcomes, which is not so evident in the case of high degree of conscientiousness among the female employees. Considering the fact that the survey research was conducted within the organization 
that is operating in the society with strong traditional values, where gender roles are largely divided, it is not unusual to consider that the role of the females should be focused on taking care of the family and the household (in the form of managing the family finance, controlling the children's success in school, planning the holidays for the whole family and similar responsibilities), so conscientiousness, as a dimension of the female's personality, is something that is expected. Therefore, these research results could be also partly explained by the expectation of the male employees that the high level of their conscientiousness at work should be particularly rewarded with higher salary. Wiersma and Kappe (2017) also indicate the correlation between conscientiousness and the pay facet of job satisfaction. Generally observed, they state that conscientiousness is difficult to observe throughout the selection process of the candidates for specific business position, but they also indicate that salaries of conscientious employees grow quicker, mainly on the basis of their intrinsic motivation and good organization (Wiersma \& Kappe, 2017).

The research results also indicate that the correlation coefficient between conscientiousness and the rewards facet of job satisfaction among the sub-sample of the male employees is negative and significantly different from zero, which is not the case with the sub-sample of the female employees. An explanation related to this research result is analogous to the previous one related to the level of correlation between conscientiousness and the pay facet of job satisfaction in the sub-sample of the male employees. Thus, in the Serbian society, males with a high degree of conscientiousness have an increased need, but also the possibility, to earn recognition for their achieved business results. It is a general opinion that within the Serbian society, females still do not have an opportunity to achieve the same progress within the business environment as the men have. Aware of this fact, females do not have high expectations that their high level of conscientiousness will be rewarded through adequate recognition, so the degree of misbalance between their expectations and the reality is lower, resulting in an insignificant change in the level of satisfaction with rewards with the increase in the level of conscientiousness among the female employees. This is similar to the findings that gender plays a role in determining the level of employee engagement, with female workers having enhanced work-life balance problems (Srivastava \& Bansal, 2016)

Neuroticism and the facets of job satisfaction. According to the research results, a moderating effect was found in male employees on the relationship between neuroticism and benefit satisfaction. In this sample, the increase in neuroticism in male employees is accompanied by a significant increase in satisfaction with benefits, as opposed to female employees. Given that a high degree of neuroticism, among other things, results in enhanced concern and pressure, a possible explanation for the results is that male employees are satisfied with the practice of benefits within this organization, including recreation and rehabilitation in wellknown resorts, which enables them to reduce stress levels. One of the points to measure benefit satisfaction is: I am satisfied with the benefits (rewards and rewards) I receive. On the other hand, female employees may have higher expectations in order to be satisfied with the benefits, especially if their distinct personality dimension is neuroticism.

\subsection{Moderation effects in case of female employees}

Agreeableness and the facets of job satisfaction. An increase in the level of personality dimension labelled as agreeableness in the sub-sample of the female employees is followed by a decrease in the benefits facet of job satisfaction. The employees with a high level of agreeableness are characterized by the willingness to help others and to provide the necessary pieces of advice for new employees in performing their business tasks, replacing the colleagues when it is necessary, sharing the knowledge with other colleagues in a team, showing the understanding for possible colleagues' mistakes in performing the business tasks and similar attitudes and behaviours. Considering the fact that chances for advancement within the hierarchical scale are thinner for female employees (Srivastava \& Bansal, 2016), it is not surprising that females are directing their expectations to gaining non-material benefits and, therefore, their disappointment could be greater if their expectations are not fully met.

Conscientiousness and the facets of job satisfaction. With increasing the value of personality dimension conscientiousness satisfaction with benefits decreases for female employees. A possible explanation for the result is that female employees with the pronounced personality dimension of conscientiousness, which implies that they are well organized, approach their duties with great care and perform them in a timely manner, expect adequate rewards for their dedication, self-discipline and high quality of work performed, while one of the points for measuring satisfaction with benefits is: "There are benefits we do not receive but we should be receiving them". If there is a discrepancy between the expected and realized rewards, there will be dissatisfaction with this facet of job satisfaction, especially for female employees who are more sensitive to the absence of rewards (gifts) if they are expected. 
Within the Serbian society, the possibility of advancement within the hierarchical scale is still not equally accessible to female and male employees, so it could be said that females are not fully able to meet the need regarding the self-actualization, which might result in higher level of their willingness for satisfying the need for recognition (by gaining the non-material benefits) to a greater extent. Therefore, it is possible that nonmaterial benefits in this organization are perceived as a compensation for different inequalities. In numerous Western companies, females are often employed within the head positions of the whole organization, or some organizational units, and they are extremely successful. However, the percentage of successful female managers is still very small in transitional societies such as Serbian, which may be related to the difficulties in overcoming the multi-role expectations related to gaining the balance between the family and business obligations (Srivastava \& Bansal, 2016).

Neuroticism and the facets of job satisfaction. With the increase in neuroticism in female employees, the satisfaction with the relationship with superiors is increasing. As one of the characteristics of a person with pronounced neuroticism is the presence of dissatisfaction, concern and the presence of pressure, it is especially important for such persons to have a good relationship with their superiors, as it can help them to reduce the pressure at work. Among the items that measure satisfaction with a supervisor are questions related to assessing the fair attitude of a supervisor towards an employee, as well as the question of assessing how much a supervisor shows interest in the feelings of employees. High scores related to these items indicate that the superiors are, in the estimation of female employees, empathetic and fair, which is especially significant for female employees with high levels of neuroticism. The "emotional dimension" of the quality of interpersonal relationships has an added value for female employees and they are encouraged to contact the manager when having problems, which is very important for establishing a high level of mutual trust.

Women with a dominant neuroticism dimension, characterized by the feeling of stress and pressure, are additionally satisfied with this job satisfaction facet if they perceive their superior as a supporting and understanding person. On the contrary, male respondents may have certain "brakes" in presenting their problems openly to their superiors, inter alia because of the stereotype that men should show firmness in coping with the difficulties and therefore prefer to find solutions to stressful situations by themselves (Fiske, 2018).

Conclusion

According to the research results, it is recommendable to create such an organizational culture in which the management will have the freedom to make a decision on providing the rewards, depending on the employees' personality dimension assessment, their motivational preferences, as well as their business performances. For example, in case of extraversion, according to the research results, the rewarding system should be largely based on material stimulation, which may have a particularly beneficial effect among the male extravert employees in this organization. Furthermore, management should provide an establishment of transparent criteria for rewarding the employees, including clear standards for evaluation of their performances, in order to establish a realistic estimate of the conscientiousness among the employees and to ensure their positive effects on business results of the entire organization. Also, the management should realize that there are specific differences in the degree of communication needs among the employees. Therefore, it is necessary to individualize the scope and the quality of communication with employees, in order to achieve their satisfaction regarding the communication facet, which is especially important before the upcoming organizational changes, such as privatization. Therefore, the leaders of this organization should initiate and encourage the establishment of individualized contact with their employees, especially during the organizational changes, when good correlation with the manager is of importance for all employees. Furthermore, it is important to provide the possibility for female employees to apply for various business tasks with a complex degree of responsibility, in accordance with their skills, which will reduce their dissatisfaction with the benefits and allow them to focus on other aspects of job satisfaction. Finally, the management should consider balancing rewards according to the employees' expectations and their contributions, leading to the development of good interpersonal correlations and boosting the employee performances.

\section{Acknowledgment}

This research is part of the project 'Transformation of geospace in Serbia - past, current problems and solution proposals', approved by the Ministry of Education, Science and Technological Development of Republic of Serbia (project registration number: $176020 \mathrm{OI}$ ). 


\section{REFERENCES}

[1] Al-Ajmi, R. (2006). The effect of gender on job satisfaction and organizational commitment in Kuwait. International Journal of Management, 23(4), 838-943. Retrieved from:

[2] Antoncic, B., Bratkovic Kregar, T., Singh, G., \& DeNoble, A. F. (2015). The Big Five Personality-Entrepreneurship Correlationship: Evidence from Slovenia. Journal of Small Business Management, 53(3), 819-841. DOI: 10.1111/jsbm.12089

[3] Arthaud-Day, M.L., Rode, J.C., \& Turnley, W.H. (2012). Direct and contextual effects of individual values on organizational citizenship behavior in teams. Journal of Applied Psychology, 97(4), 792. DOI: 10.1037/a0027352

[4] Atari, M., Barbaro, N., Sela, Y., Shackelford, T. K., \& Chegeni, R. (2017). The Big Five personality dimensions and mate retention behaviors in Iran. Personality and Individual Differences, 104, 286-290. DOI: $10.1016 /$ j.paid.2016.08.029

[5] Berglund, V., Johansson Seva, I., \& Strandh, M. (2016). Subjective well-being and job satisfaction among self-employed and regular employees: does personality matter differently?. Journal of Small Business \& Entrepreneurship, 28(1), 55-73. DOI: 10.1080/08276331.2015.1115699

[6] Bui, H. T. (2017). Big Five personality traits and job satisfaction: Evidence from a national sample. Journal of General Management, 42(3), 21-30. DOI: 10.1177\%2F0306307016687990

[7] Burke, R.J., Graham, J., \& Smith, F. (2005). Effects of reengineering on the employee satisfaction-customer satisfaction correlationship. The TQM Magazine, 17(4), 358-363. DOI: $10.1108 / 09544780510603198$

[8] Chai, S., Das, S., \& Rao, H.R. (2012). Factors affecting bloggers' knowledge sharing: An investigation across gender. Journal of Management Information Systems, 28(3), 309-341. DOI: 10.2753/MIS07421222280309

[9] Chi, C.G., \& Gursoy, D. (2009). Employee satisfaction, customer satisfaction and financial performance: An empirical examination. International Journal of Hospitality Management, 28(2), 245-253. DOI: 10.1016/j.ijhm.2008.08.003

[10] Chiorri, C., Marsh, H. W., Ubbiali, A., \& Donati, D. (2016). Testing the factor structure and measurement invariance across gender of the Big Five Inventory through exploratory structural equation modelling. Journal of personality assessment, 98(1), 88-99. DOI: 10.1080/00223891.2015.1035381

[11] Choi, C.H., Kim, T., Lee, G., \& Lee, S.K. (2014). Testing the stressor-strain-outcome model of customerrelated social stressors in predicting emotional exhaustion, customer orientation and service recovery performance. International Journal of Hospitality Management, 36, 272-285. DOI: 10.1016/j.ijhm.2012.09.009

[12] Cronin, J.J.Jr., Brady, M.K., \& Hult, G.T.M. (2000). Assessing the effects of quality, value and customer satisfaction on consumer behavioral intentions in service environments. Journal of Retailing, 76(2), 193218. DOI: $10.1016 /$ S0022-4359(00)00028-2

[13] De Leaniz, P.M.G., \& Rodríguez, I.R.D.B. (2015). Exploring the antecedents of hotel customer loyalty: A social identity perspective. Journal of Hospitality Marketing Management, 24(1), 1-23. DOI: $10.1080 / 19368623.2014 .891961$

[14] Donegani, C.P., McKay, S., \& Moro, D. (2012). A dimming of the 'warm glow'? Are non-profit workers in the UK still more satisfied with their jobs than other workers. Advances in the Economic Analysis of Participatory \& Labor-Managed Firms, 13, 313-342. DOI: 10.1108/S0885-3339(2012)0000013015

[15] EPS (2018), Electric power industry of Serbia, Company profile 2018, Retrieved from: http://www.eps.rs/eng/Documents/Kompanijski\%20Profil\%202018\%20-\%20ENG.pdf

[16] Eskildsen, J., Kristensen, K., \& Gjesing Antvor, H. (2010). The correlationship between job satisfaction and national culture. The TQM Journal, 22(4), 369-378. DOI: 10.1108/17542731011053299

[17] Eysenck, H. J. (1967). The biological basis of personality. Springfield, IL: Thomas

[18] Fiske, S. T. (2018). Controlling other people: The impact of power on stereotyping. In Social Cognition: Selected Works of Susan Fiske (pp. 101-115). Taylor and Francis.

[19] Frye, W., \& Mount, D. (2007). An examination of job satisfaction of general managers based on hotel size and service type. Journal of Human Resources in Hospitality \& Tourism, 6(2), 109-134. DOI: 10.1300/J171v06n02_06

[20] Hahn, E., Gottschling, J., König, C. J., \& Spinath, F. M. (2016). The heritability of job satisfaction reconsidered: Only unique environmental influences beyond personality. Journal of Business and Psychology, 31(2), 217-231. DOI: 10.1007/s10869-015-9413-x

[21] Harari, M. B., Thompson, A. H., \& Viswesvaran, C. (2018). Extraversion and job satisfaction: The role of trait bandwidth and the moderating effect of status goal attainment. Personality and Individual Differences, 123, 14-16. DOI: 10.1016/j.paid.2017.10.041.

[22] Howard, P. J., Medina, P. L., \& Howard, J. M. (1996). The Big Five Locator: A Quick Assessment Tool for Consultants and Trainers. In Pfeiffer, J. W. \& Goodstein D. L. (Eds.), Developing Human Resources (pp. 199-122). San Diego, CA: Pfeiffer and Company. 
[23] Hsieh, H. H., \& Huang, J. T. (2017). Core self-evaluations and job and life satisfaction: The mediating and moderated mediating role of job insecurity. The Journal of Psychology, 151(3), 282-298. DOI: 10.1080/00223980.2016.1270888

[24] Hur, W.M., Moon, T.W., \& Jung, Y.S. (2015). Customer response to employee emotional labor: The structural correlationship between emotional labor, job satisfaction and customer satisfaction. Journal of Services Marketing, 29(1), 71-80. DOI: 10.1108/JSM-07-2013-0161

[25] limura, S., \& Taku, K. (2017). Gender differences in correlationship between resilience and Big Five Personality Traits in Japanese adolescents. Psychological reports, 121(5), 920-931. DOI: $10.1177 \% 2 F 0033294117741654$

[26] IImarinen, V. J., Vainikainen, M. P., Verkasalo, M., \& Lönnqvist, J. E. (2015). Why are extraverts more popular? Oral fluency mediates the effect of extraversion on popularity in middle childhood. European Journal of Personality, 29(2), 138-151. DOI: 10.1002/per.1982.

[27] Ýrengün, O., \& Arýkboða, P. (2015). The effect of personality traits on social entrepreneurship intentions: a field research. Procedia-Social and Behavioral Sciences, 195, 1186-1195. DOI: 10.1016/j.sbspro.2015.06.172

[28] Janicijevic, N. (2017). Contradictory values in the process of organizational change: A case study. Management: Journal of Sustainable Business and Management Solutions in Emerging Economies, 22(2), 29-36. DOI: 10.7595/management.fon.2017.0009.

[29] Judge, T. A., \& Zapata, C. P. (2015). The person-situation debate revisited: Effect of situation strength and trait activation on the validity of the Big Five personality traits in predicting job performance. Academy of Management Journal, 58(4), 1149-1179. DOI: 10.5465/amj.2010.0837

[30] Jung, K., Jae Moon, M., \& Hahm, S.D. (2007). Do age, gender and sector affect job satisfaction? Results from the Korean labor and income panel data. Review of Public Personnel Administration, 27(2), 125-146. DOI: 10.1177\%2F0734371X06289229

[31] Kaiser, L. (2007). Gender-job satisfaction differences across Europe. International Journal of Manpower 28(1), 75-94. DOI: 10.1108/01437720710733483

[32] Karin Andreassi, J., Lawter, L., Brockerhoff, M., \& Rutigliano, P.J. (2014). Cultural impact of human resource practices on job satisfaction: A global study across 48 countries. Cross Cultural Management, 21(1), 55-77. DOI: 10.1108/CCM-05-2012-0044

[33] Kelly, J. (1989). Gender, pay and job satisfaction of faculty in journalism. Journalism Quarterly, 66(2), 446-52. DOI: $10.1177 \% 2 F 107769908906600226$

[34] Kilili, R., \& Bozdaðlar, H. (2013). Comparing job satisfaction among managers and employees: An empirical evidence leisure sector in North Cyprus. Interdisciplinary Journal of Contemporary Research in Business, 5(2), 509-516. ISSN 2073-7122 Retrieved from:

[35] Koyuncu, M., Burke, R., \& Fiksenbaum, L. (2006). Work experience and satisfaction of male and female professors in Turkey: Signs of progress? Equal Opportunities International, 25(1), 38-47. DOI: 10.1108/02610150610645959

[36] Kruyen, P. M., Keulemans, S., Borst, R. T., \& Helderman, J. K. (2019). Searching for the renaissance bureaucrat. International Journal of Public Sector Management, 33(1), 22-44. DOI: 10.1108/IJPSM-07-20190195,

[37] Li, C-H., \& Chang, C-M. (2016). The influence of trust and perceived playfulness on the correlationship commitment of hospitality online social network-moderating effects of gender. International Journal of Contemporary Hospitality Management, 28(5), 924-944. DOI: 10.1108/IJCHM-05-2014-0227

[38] Liang, C. T., Chia, T. L., \& Liang, C. (2015). Effect of personality differences in shaping entrepreneurial intention. Internafional Journal of Business and Social Science, 6(4.1), 166-176. ISSN 2219-1933 (Print), 2219-6021 (Online) DOI: 10.30845/ijbss Retrieved from:

[39] Locke, E. A. (1976). The nature and causes of job satisfaction. In M. D. Dunnette (Ed.), Handbook of industrial and organizational psychology (1297-1343). Chicago, IL: Rand McNally.

[40] Loh, J., Restubog, S.L.D., \& Gallois, C. (2010). Attitudinal outcomes of boundary permeability. Cross Cultural Management, 17, 118-134. DOI: 10.1108/13527601021038697

[41] Lopez, T.B., Babin, B.J., \& Chung, C. (2009). Perceptions of ethical work climate and person-organization fit among retail employees in Japan and the US: A cross-cultural scale validation. Journal of Business Research, 62(6), 594-600. DOI: 10.1016/j.jbusres.2008.05.018

[42] Lucas, R.E., Diener, S., Alexander, S., Eunkook, M., \& Shao, L. (2000). Cross-cultural evidence for the fundamental feature of extraversion. Journal of Personality and Social Psychology, 79(3), 452-458. DOI: 10.1037/0022-3514.79.3.452

[43] Maruping, L.M., \& Magni, M. (2012). What's the weather like? The effect of team learning climate, empowerment climate and gender on individuals' technology exploration and use. Journal of Management Information Systems, 29(1), 79-113. DOI: 10.2753/MIS0742-1222290103

[44] Matanovic, J. (2009). Osobine ličnosti kao prediktori zadovoljstva poslom. Primenjena psihologija, 2(3) 327-338. DOI: 10.19090/pp.2009.4.327-338 
[45] Mora, T., \& Ferrer-i-Carbonell, A. (2009). The job satisfaction gender gap among young recent university graduates: Evidence from Catalonia. Journal of Socio-Economics, 38, 581-589. DOI: 10.1016/j.socec.2009.02.003

[46] Oehler, A., \& Wedlich, F. (2018). The correlationship of extraversion and neuroticism with risk attitude, risk perception, and return expectations. Journal of Neuroscience, Psychology, and Economics, 11(2), 63-92. DOI: $10.1037 / \mathrm{npe0000088.}$

[47] Okpara, J., Sqillace, M., \& Erondu, E. (2005). Gender differences and job satisfaction: A study of university teachers in the United States. Women in Management Review, 20(3/4), 177-190. DOI: $10.1108 / 09649420510591852$

[48] Otken, A. B., \& Cenkci, T. (2015). Big Five personality traits and organizational dissent: The moderating role of organizational climate. Business and Economics Research Journal, 6(2), 1-24. ISSN: 13092448 Retrieved from:

[49] Pantouvakis, A., \& Bouranta, N. (2013). The intercorrelationship between service features, job satisfaction and customer satisfaction: Evidence from the transport sector. The TQM Journal, 25(2), 186201. DOI: $10.1108 / 17542731311299618$

[50] Petrovic, M.D., Jovanovic, T., Markovic, J.J., Armenski, T., \& Markovic, V. (2014). Why should gender differences in hospitality really matter? A study of personnel's service orientation and job satisfaction in hotels. Economic Research, 27(1), 799-817. DOI: 10.1080/1331677X.2014.975516

[51] Siegling, A. B., Furnham, A., \& Petrides, K. V. (2015). Trait emotional intelligence and personality: Gender-invariant linkages across different measures of the Big Five. Journal of Psychoeducational Assessment, 33(1), 57-67. DOI: 10.1177\%2F0734282914550385

[52] Spector, P.E. (1997). Job satisfaction: Application, assessment, causes and consequences. Sage Publications.

[53] Srivastava, D. K., \& Bansal, N. (2016). Creating employee engagement in organizations in India: Role of human resource processes. International Journal of Innovative Research and Development, 5(6), 41 47. ISSN 2278 - 0211 (Online) Retrieved from:

[54] Sun, J., Kaufman, S. B., \& Smillie, L. D. (2018). Unique associations between big five personality aspects and multiple dimensions of well being. Journal of personality, 86(2), 158-172. DOI: 10.1111/jopy.12301

[55] Tansel, A., \& Gazîoðlu, P. (2014). Management-employee correlations, firm size and job satisfaction. International Journal of Manpower, 35(8), 1260-1275. DOI: 10.1108/IJM-09-2014-0179

[56] Walker, M., \& Vetter, T. (2016). Personality Processes and Individual Differences: Changing the personality of a face: Perceived Big Two and Big Five personality factors modeled in real photographs. Journal of Personality and Social Psychology, 110(4), 609-624. DOI: 10.1037/pspp0000064

[57] Wiersma, U. J., \& Kappe, R. (2017). Selecting for extroversion but rewarding for conscientiousness. European Journal of Work and Organizational Psychology, 26(2), 314-323. DOI: 10.1080/1359432X.2016.1266340.

[58] Yeh, S. C. J., Yuan, K. S., Chen, S. H. S., Lo, Y. Y., Chou, H. C., Huang, S., \& Wan, T. T. (2016). The moderating effect of leadership on the correlationship between personality and performance. Journal of Nursing Management, 24(7), 869-883. DOI: 10.1111/jonm.12391

Received: 2019-05-09

Revision requested: 2019-09-30

Revised: 2020-01-10 (2 revisions)

Accepted: 2020-02-06

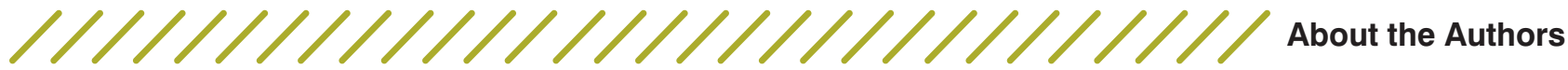

\section{Milena Nedeljković Knežević \\ University of Novi Sad, Faculty of Sciences, Serbia e-mail: milena.nedeljkovic@dgt.uns.ac.rs}

Milena Nedeljkovic Knezevic is an Associate professor at the Faculty of Sciences, University of Novi Sad. She graduated with PhD in Human resource management in 2009 at the Faculty of Technical Sciences, University of Novi Sad. She defended her second PhD dissertation in 2016, in the area of Behavioral economics at the Faculty of Economics and the Faculty of Philosophy (interdisciplinary), University of Novi Sad. Her research interests are within the area of management, management of human

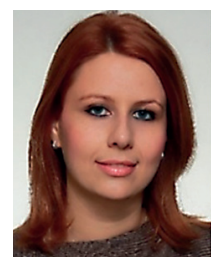
resources, organizational behaviour and entrepreneurship. 
Slađana Nedeljković EPS, RB Kolubara, Serbia e-mail: slakospo@gmail.com

Sladjana Nedeljković, graduated and earned her interdisciplinary PhD in sociology and tourism at the University of Novi Sad. She is employed at the mining basin "Kolubara".

She is actively engaged in organization and lecturing at cultural and humanitarian manifestations. Her research interests include: cultural tourism, sociology of culture, organizational culture.

\section{Maja Mijatov,PhD \\ University of Novi Sad, Faculty of Sciences, Serbia e-mail:majamijato@gmail.com;}

Maja Mijatov is a research associate at the Faculty of Sciences, University of Novi Sad. Her main fields of interest are the following: business ethics, ethical climate, corporate

social responsibility, business performances, job satisfaction, organizational
commitment, service orientation, management, human resources.

social responsibility, business performances, job satisfaction, organizational
commitment, service orientation, management, human resources.

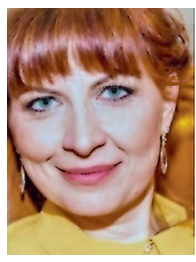

$$
\begin{array}{r}
\text { Jelena Vukonjanski Srdić, PhD } \\
\text { University Educons, Project Management College, Serbia } \\
\text { e-mail: jelena.vukonjanski@pmc.edu.rs }
\end{array}
$$

Associate professor at the Department of Management and Project Management.

Her research interests are: Organizational and National Culture (GLOBE model), Organizational Behavior, Human Resource Management, Leadership and Organizational management.
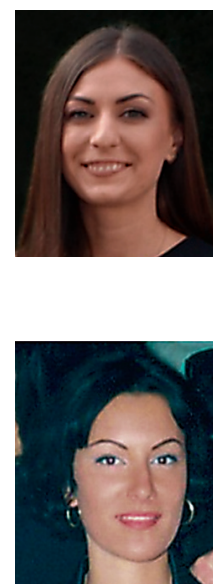